\title{
MIXED SIGNALS
}

The depression drug TC-5214 binds to nicotinic receptors (NNRs) on dendrites, diminishing the effect of the neurotransmitter acetylcholine (ACh), which has been linked to depression.
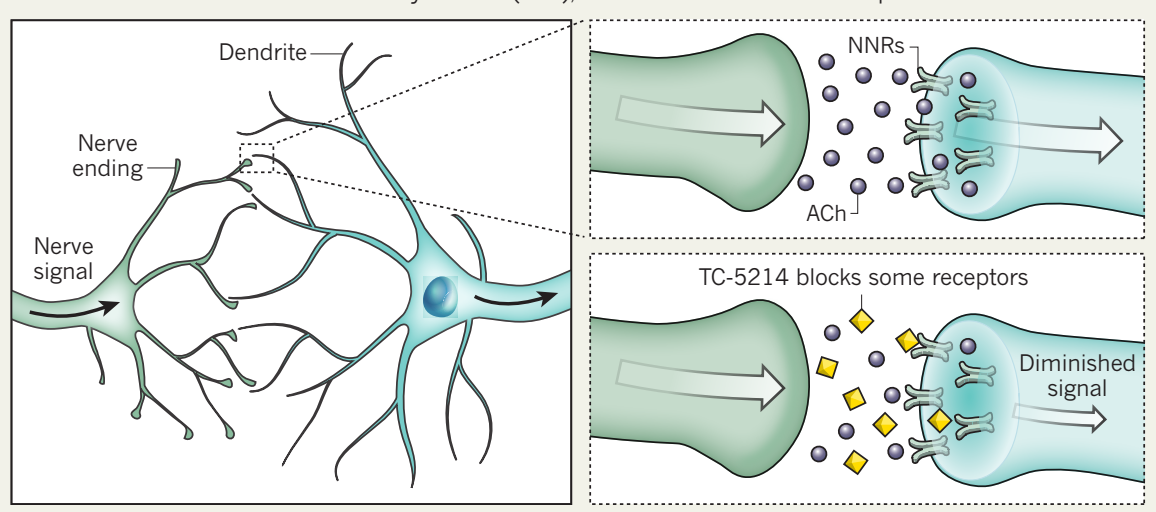

CLINICAL TRIALS

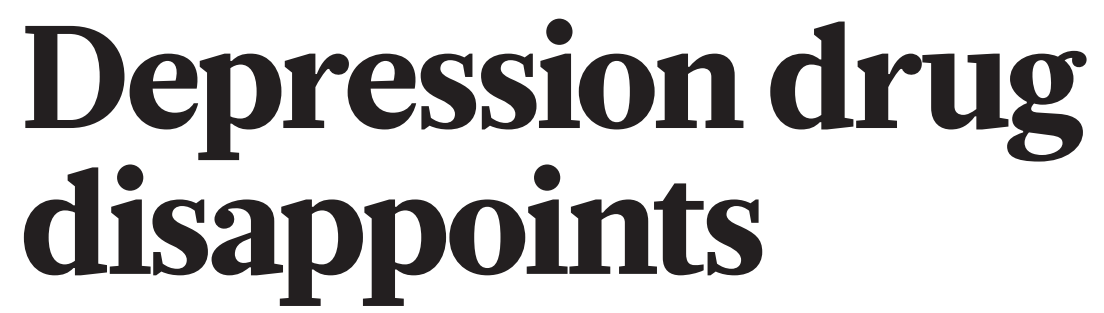

Failure of a promising compound casts a shadow on others.

\section{BY HEIDI LEDFORD}

$\mathrm{I}$ would not be the first psychiatric drug to run aground in a large study after sailing through early trials. But even though TC-5214 has failed to significantly relieve major depression in a phase III trial and investors are fleeing, some analysts and scientists argue that the setback need not spell the end for the drug, nor for other compounds that act on nicotinic receptors in nerve cells.

On 8 November, Targacept, a drug company based in Winston-Salem, North Carolina, announced that TC-5214 had performed no better than placebo in one of four phase III trials. The results are a disappointment to clinicians eager for an innovative antidepressant. Because the drug exploits a previously untried mechanism, it might have helped the roughly one-third of people with depression who do not respond to current therapies ${ }^{1}$. "We really need new options," says Noah Philip, a psychiatrist at Brown University in Providence, Rhode Island. "People were very eager to see what this drug would do."

Results from the other trials are expected by early 2012, but some analysts are pessimistic; Targacept's stock fell by $60 \%$ after the announcement. "I was stunned by the negative outcome," says Alan Carr, an analyst for the Needham \& Co investment bank in New York. "I don't have high expectations for the remaining three trials."

TC-5214 is a form of mecamylamine, a blood-pressure drug introduced in the 1950s.
It targets nicotinic $\alpha 4 \beta 2$ receptors (see 'Mixed signals'), which normally receive chemical signals from the neurotransmitter acetylcholine. Because excess acetylcholine has been linked to major depression ${ }^{2}$, blocking these signals might relieve the condition.

Interest in the drug's use in neuropsychiatric disorders began in the 1990s, when nicotine was seen to reduce the symptoms of Tourette's syndrome. Searching for a similar effect with a less harmful substance, researchers at the University of South Florida in Tampa investigated mecamylamine. It did not ease the tics characteristic of Tourette's syndrome, but did relieve depression and improve mood regulation in some people ${ }^{3}$.

The result caught the attention of Targacept, which licensed mecamylamine patents held by the University of South Florida. In 2009, the London-based pharmaceutical company AstraZeneca backed TC-5214 with US\$200 million up front, and up to $\$ 1$ billion in milestone payments. That year, Targacept reported that in phase II trials with an approved antidepressant, TC-5214 had few side effects and produced a six-point improvement on the Hamilton rating scale for depression.

Last week's discouraging result "is not necessarily the end of this drug, although you might think so if you just look at Targacept's share price", says Daniel Chancellor, a health-care analyst for Datamonitor, a market-research firm in London. Targacept needs to succeed in only two of its phase III trials to gain approval, says Merouane Bencherif, head of preclinical research at the company. Chancellor notes that Forest Laboratories, based in New York, reported in January that its candidate antidepressant, levomilnacipran, had failed in a phase III trial, yet in July the company announced that the drug had significantly improved symptoms in another phase III trial..

Companies such as Targacept also hold high hopes for nicotinic-receptor modulators that stimulate, rather than inhibit, the acetylcholine pathway. So far, the only approved such modulator is varenicline (Chantix/Champix), a drug to help people stop smoking that has come under fire over possible psychiatric side effects ${ }^{4}$.

With backing from AstraZeneca, Targacept is testing two compounds against Alzheimer's disease. Other companies, including Pfizer, based in New York, have invested in nicotinicreceptor modulators to treat Alzheimer's disease and attention-deficit hyperactivity disorder (see table).

The discouraging news about TC-5214 "just shows that there are some unknowns in the biology here", says Carr, who cautions that it is too soon to write off the drug class. "I think it's just a matter of time before something does come along that makes it past that final hurdle." -

1. Rush, A. J. et al. Am. J. Psychiatry 163, 1905-1917 (2006).

2. Shytle, R. D. et al. Mol. Psychiatry 7, 525-535 (2002).

3. Shytle, R. D., Silver, A. A. \& Sanberg, P. R. Biol Psychiatry 48, 1028-1031 (2000)

4. Nature 466,677 (2010)

\begin{tabular}{|c|c|c|c|}
\hline Drug & Company & Indication & Stage \\
\hline $\begin{array}{l}\text { Chantix/Champix } \\
\text { (varenicline) }\end{array}$ & Pfizer & Smoking cessation & Approved \\
\hline TC-5214 & AstraZeneca/Targacept & Major depressive disorder & Phase III \\
\hline AZD3480 & AstraZeneca/Targacept & $\begin{array}{l}\text { Alzheimer's disease } \\
\text { Adult attention-deficit hyperactivity } \\
\text { disorder (ADHD) }\end{array}$ & $\begin{array}{l}\text { Phase Ilb } \\
\text { Phase II }\end{array}$ \\
\hline CP-601927 & Pfizer & Major depressive disorder & Phase II \\
\hline AZD1446 & AstraZeneca/Targacept & $\begin{array}{l}\text { Alzheimer's disease } \\
\text { Adult ADHD }\end{array}$ & $\begin{array}{l}\text { Phase I } \\
\text { Phase II }\end{array}$ \\
\hline
\end{tabular}

